\title{
CONSIDERATIONS ON IMPEDANCE CARDIOGRAPHY
}

\author{
Pierre Casthély, Sivam Ramanathan and Jack Chalon
}

ABStraci

\begin{abstract}
Impedance cardiography is an electronic plethy smographic technique which provides information on cardiac stroke index, myocardial performance, thoracic fluid content and peripheral circulation. The method has gained popularity in recent years because it is not invasive. While less precise in absolute terms than invasive methods the results are reproducible, and the technique accurately assesses variations in measurements. It may be used in most anaesthetized patients without the possibility of any of the complications which sometime accompany the use of more precise invasive methods.
\end{abstract}

This paper describes impedance cardiography and methods for its use.

\section{Description}

IMPEDANCE CARDIOGRAPHY is an electronic plethysmographic technique which provides information on cardiac stroke index, myocardial performance, thoracic fluid content, and peripheral circulation. The method has gained popularity in recent years because it is not invasive. Although the technique was introduced as early as $1930^{1.2}$ it was only perfected in the late sixties to meet the requirements of the Apollo space flights. In 1966, Kubicek, et at. ${ }^{3}$ had derived a formula to calculate cardiac stroke volume through changes in thoracic impedance.

The impedance $(\mathrm{z})$ offered by mammalian tissue to an alternating electric current of $100 \mathrm{kHz}$ and 4 ma is resistive in nature. The waves derived from impedance variations, occurring during the cardiac cycle, form the Impedance Cardiogram or ZCG (Figure 1). Kubicek, et al. ${ }^{3}$ investigated the origin of the impedance wave in dogs with electromagnetic flowmeters during the selective obstruction of right and left ventricular outflows. They found that the major component of the pulsatile $z$ wave was related to aortic outflow and $a$ minor fraction to right ventricular outflow. Respiratory impedance variations are electrically dampened.

A typical ZCG (Figure 1) consists of $3 \mathrm{seg}$ ments: ${ }^{2,4,5}$ (1) wave $A$ corresponds to the $P$ wave and the PR interval of the ECG, (2) wave C to the QRS complex and, thus, ventricular ejection, and (3) wave $V$ is synchronous with the protodiastolic

Pierre Casthély, M.D., Instructor; Sivam Ramanathan, M.D., Associate Professor; Jack Chalon, M.D., Professor. Department of Anesthesiology, New York University Medical Center, 550 First Avenue, New York, New York 10016.

Address reprint requests to: Pierre Casthély, M.D., New York University Medical Center, Anesthesiology H-623, 550 First Avenue, New York, New York 10016.

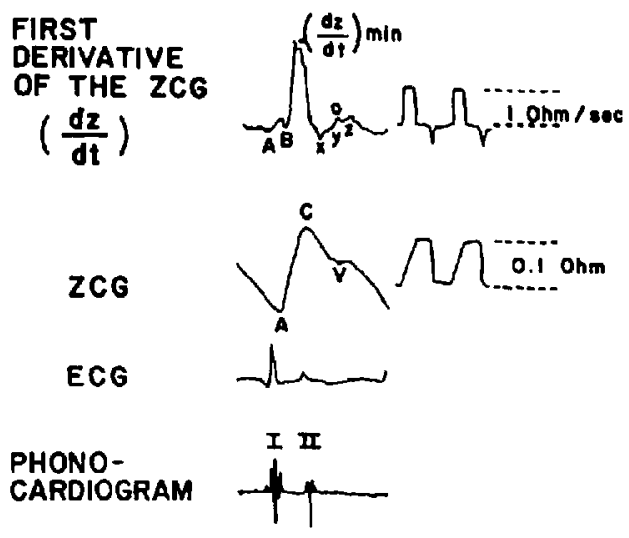

Figure I Simultaneous tracings of first derivative of the impedance cardiogram, impedance cardiogram. ECG and phonocardiogram. The first derivative tracing and the impedance cardiogram show recordings of calibration signals on the right. Points $A, B, X, Y, O$ and $Z$ of the dz/dt wave and $A, C$ and $V$ of the ZCG are explained in the text. The phonocardiogram displays the first and second heart sounds. Note that the point $X$ of the $\mathrm{dz} / \mathrm{dt}$ wave occurs at the same time as the second heart sound.

period. The first derivative of the impedance cycle (ZCG) includes points $A, B, X, Y, O$ and $Z$ (Figure 1).6 They are respectively related to atrial contraction, maximal first sound vibration, aortic and pulmonary valve closure, mitral valve opening, and the onset of the third sound. At the beginning of left ventricular ejection is a point (J) which follows $B$ and is well defined in Figure 2. The differential at the peak between $B$ and $X$ $(\mathrm{dz} / \mathrm{dt})_{\min }$ denotes maximal ventricular ejection.

\section{Utilization}

Impedance cardiography is used to calculate stroke volume. One approximates the thorax to a cylinder containing a homogeneous conduction 


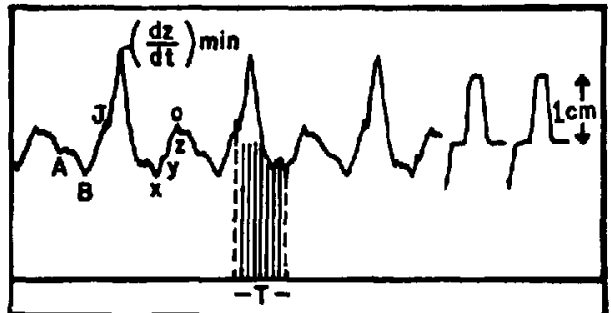

Figure 2 First derivative impedance cardiogram recorded from an adult patient. Points A, B, J, X, Y, O and $\mathrm{Z}$ are explained in the text. Point $\mathrm{J}$ corresponds to onset of rapid ejection from the left ventricle. Ventricular ejection time $T$ (in seconds) is the time interval between the points $J$ and $X$. $T$ is 0.32 seconds in this recording.

medium. ${ }^{2}$ Human chest anatomy introduces errors which vary among individuals. Therefore, the technique is more useful in following trends than in calculating absolute values.

According to Scott,' Bonjer established a relationship between impedance changes (Z) and changes in volume ( $V$ ) in a symmetrical homogeneous cylinder with a basic resistivity of $\int \mathrm{ohm} /$ centimeters, which he expressed as:

$$
\text { Formula } A \quad \mathrm{~V}=\mathfrak{f}(\mathrm{l} / \mathrm{z})^{2} \mathrm{Z}
$$

in which I was the length of the cylinder, $z$ the impedance of the cylinder and $Z$ impedance changes. The equation may be used to calculate stroke volume by substituting $Z$ by peak ventricular ejection rate multiplied by ventricular ejection time in seconds (T), or:

\section{Formula $B \quad \mathrm{~V}=\int(l / \mathrm{z})^{2}(\mathrm{dz} / \mathrm{dt})_{\min } \mathrm{XT}$}

Both haematocrit and temperature affect body resistivity.? An average resistivity value of $150 \mathrm{ohms} / \mathrm{cm}$ has thus been used to minimize these effects. ${ }^{8}$ If the haematocrit has been calculated, the resistivity becomes:

$$
\int=56 \times 8 \mathrm{e}^{0.025 \mathrm{H}}
$$

in which $\mathrm{H}$ is the haematocrit, and e the natural logarithm.

Most commercially available impedance cardiographs are portable units weighing around $8 \mathrm{~kg}$. A facultative computer incorporating an oscilloscopic display may be used but is an unnecessary expense. It can be replaced by a two-channel recorder with sweeps of 25 and $50 \mathrm{~mm} / \mathrm{sec}$ using timed chart paper.

\section{Methodology}

To obtain an impedance cardiogram, the patient wears a set of four adhesive aluminized

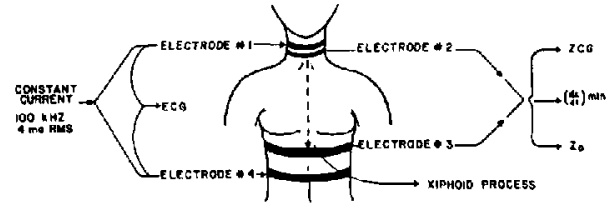

FIGURE 3 Electrode placement for using impedance cardiograph. Exact locations are described in the text. Electrodes 1 and 4 are used to pass a constant current through the chest and also delect ECG signals. The impedance cardiogram, its first derivative and the basic thoracic impedance $\left(Z_{0}\right)$ are detected by electrodes 2 and 3 .

mylar strip electrodes $2.5 \mathrm{~cm}$ wide (Figure 3 ). Strips 2 and 3, respectively, encircle the root of the neck and the thorax at the level of the xiphoid process. Strips 1 and 4 are $3 \mathrm{~cm}$ above and below strips 2 and 3 respectively. Adequate tension ensures skin contact. Patient electrodes are numbered sequentially and securely clipped to corresponding leads. The system incorporates a basic circuit which sends a $4 \mathrm{ma}$ and $100 \mathrm{kHz}$ alternating current between electrodes $I$ and 4 . The product of this current (I) and the thoracic impedance $\left(Z_{0}\right)$ generates a voltage $(E)$ equal to $I \times Z_{0}$ during its passage between electrodes 2 and $3 .^{6}$ Amplification of this signal produces the impedance cardiogram (ZCG). A phonocardiograph circuit and an ECG signal from electrodes 1 and 4 are included (Figure 1). ${ }^{9} \mathrm{ZCG},(\mathrm{dz} / \mathrm{dt})_{\min }, \mathrm{ECG}$ and basic thoracic impedance $\left(Z_{0}\right)$ can be obtained through output jacks connected to a recorder. ${ }^{9}$ A warming up time of 20 minutes is re. quired for efficient operation. The phonocardiograph identifies point $X$ (or second heart sound); however, since this point is usually well defined, the addition of phonocardiography is often an unnecessary additional refinement. Patient movements (including breathing) are dampened by a trace stabilizing control which eliminates baseline shifts.

Optimal results are obtained by starting the tracing during voluntary apnoea. To simplify stroke volume calculations the cardiograph is switched to calibration and the gain adjusted to $1 \mathrm{~cm}$ for a signal of $1 \mathrm{ohm}$. The $(\mathrm{dz} / \mathrm{dt})_{\min }$ is recorded during at least 6 heart beats. The $Z_{0}$ control is then adjusted to the "hold" position for recall. Each set of recordings is followed by a calibration tracing signal to estimate $(\mathrm{dz} / \mathrm{dt})_{\min }$ amplitude and ventricular ejection time. The $(\mathrm{dz} / \mathrm{dt})_{\min }$ and stroke volume calculation are shown in Figure 2. Vertical lines indicate $0.04 \mathrm{sec}$ intervals. Ventricular ejection time is measured from $\mathrm{J}$ to $\mathrm{X}(0.32 \mathrm{secs})$. The amplitude of 
$(\mathrm{dz} / \mathrm{dt})_{\min }$ is $1.4 \mathrm{~cm}$ which, when divided by the amplitude of the calibration signal $(1 \mathrm{~cm})$, provides the first derivative of impedance during ventricular ejection. With a $Z_{0}$ of $22 \mathrm{ohms}$, a haematocrit of 44 per cent, resistivity factor of $150 \mathrm{ohm} / \mathrm{cm}$, electrodes 2 and $3,24 \mathrm{~cm}$ apart, and a heart rate of $65 / \mathrm{min}$, the stroke volume can be calculated from Formula $B$, previously given; which becomes:

Stroke Volume $=150(24 / 22)^{2} \times 1.4$

$$
\times 0.32=80 \mathrm{ml}
$$

and the cardiac output, $80 \times 65=(5.200 \mathrm{ml} / \mathrm{min}$, or) $5.2 \mathrm{l} / \mathrm{min}$.

Many authors have investigated the reliability of the measurement of cardiac output by the impedance technique. ${ }^{10-18}$ The general opinion is that overestimations are frequent but reproducibility accurate (when compared with thermodilutional techniques). Results can be considerably improved by assessing blood resistivity rather than using a fixed mean value of $150 \mathrm{ohms} / \mathrm{cm} .{ }^{10}$ However, in the very obese, resistivity must be raised to $175 .{ }^{12}$ Pate, et al.,$^{13}$ who compared impedance cardiac outputs against dye dilution technique, the radioisotope method, pulse contour assessments and electromagnetic flowmetry, confirmed that the plethysmographic technique erred towards overestimation but accurately assessed variations in measurements. Inaccuracies have been ascribed to right to left shunts, inequalities in velocity during left ventricular ejection, pectoral assymetry and influence of right ventricular ejection on pulsatile Z. ${ }^{14}$

\section{Additional considerations}

The first derivative of the impedance cardio gram can be used to assess other indices of myocardial performance. Among these are:

1. The Heather Index obtained by dividing maximum dz/dt by the time elapsed since the preceding $R$ wave of the ECG (or RZ interval in ohms $/ \mathrm{sec}^{2}$ ) which approximates the ratio of the pre-ejection phrase by the ventricular ejection time, ${ }^{19}$

2. Left Ventricular Ejection Time measured from the $\mathrm{dz} / \mathrm{dt}$ wave form which yields results similar to those obtained by the study of the pulse wave tracing, ${ }^{19}$ and

3. The Siegel Index ${ }^{20}$ which claims that the point $B$ of the $\mathrm{dz} / \mathrm{dt}$ wave form correlates well with the isovolumetric period of ventricular contraction $(\mathrm{dz} / \mathrm{dt})_{\max }$ and can, therefore, be used to assess myocardial isometric time-tension relationships.

Accumulation of fluid in the chest will alter basic thoracic impedance $\left(Z_{0}\right)$. Pomerantz, et al. ${ }^{21,22}$ noted that as little as $50 \mathrm{ml}$ of fluid in the pleural cavity produced significant impedance changes. Therefore, these measurements can be used both for the diagnosis of pleural effusions and early pulmonary edema and to follow their course. Luepper, et al. ${ }^{23}$ found that changes in $Z_{0}$ could quantitate changes in central blood volume. Keller and Blumberg ${ }^{24}$ noted impedance changes during haemodialysis. Pulmonary emboli, pneumothorax and pulmonary atelectasis have been diagnosed by Berman, et al. ${ }^{25}$ by the impedance method. Impedance cardiography can also assess peripheral circulatory adequacy if encircling electrodes are placed around the affected extremity. ${ }^{9}$ Finally, all these manoeuvres can be carried out in most anaesthetized patients, especially when invasive methods are considered to be contraindicated. The technique is especially useful when unexpected circulatory failure or increased pulmonary fluid content occur during surgery.

\section{REFERENCES}

1. Scott, N. Bio-impedance measurement, In Non-invasive Clinical Measurement. Tayler, D.E.M., Whamond, J., Eds., Baltimore: University Park Press (1977).

2. Miller, J.C. \& Horvath, S.M. Impedance cardiography. Psychophys 15: 80(1978).

3. Kubicek, W.G., KotTKe, F.J., Ramos, M.U., et al. The Minnesota impedance cardiography-theory and applications. Biochem. Eng. 9: 410(1974).

4. Van DeWater, J.M., Mount, B.E.. Barela. J.R., et al. Monitoring the chest with impedance. Chest 64: 597 (1973).

5. Karnegis, J.N. \& Kubicek, W.G. Physiological correlates of the cardiac thoracic impedance waveform. Am. Heart J. 79: 519 (1970).

6. LABABIDI, Z., EHMKE, D.A., DURNin, R.D., etal. The first derivative thoracic impedance cardiogram. Circul. 4I: 651 (1970).

7. GedDes, L.A. \& Sadler, C. The specific resistance of blood at body temperature. Med. Bio. Eng. 1/: 336(1973).

8. Denniston. J.C., Maher, J.T., Reeves, J.T., et al. Measurement of cardiac output by electrical impedance at rest and during exercise. J. Appl. Physiol. 40: 91 (1976).

9. IFM/Impedance Cardiography Instruction Manual (1975).

10. Secher, N.J., Thomsen, A. \& Arnsbo, P. Measurement of rapid changes in cardiac stroke volume. An evaluation of the impedence cardiography method. Acta Anaesth. Scand. 21: 353 (1977).

11. Rasmussen, J.P., Sorensen, B. \& Kann, T. Evaluation of impedance cardiography as a non- 
invasive means of measuring systolic time intervals and cardiac output. Acta Anaesth. Scand. 19: 210 (1975).

12. Rasmussen, J.P., Eriksen, J. \& Andersen, J. Evaluation of impedance cardiography during anesthesia in extremely obese patients. Acta Anaesth Scand 21: 342 (1977).

13. Pate, T.D., Baker, L.E. \& Rosborough, J.P. The simultaneous comparison of the electrical impedance method of measuring stroke volume and cardiac output with four other methods. Cardiovas. Res. Cen. Bull. 14: 39 (1975).

14. Lababidi, Z. Ehmke, D.A., Durnin, R.E., et al Evaluation of impedance cardiac output in children. Pediatrics 47: 870 (1971).

15. Gabriel, S.. Atterhög, J.H., Orö, L. et at Measurement of cardiac output by impedance cardiography in paticnts with myocardial infarction. Scand. J. Clin. Lab. Invest. 36: 29 (1976).

16. JUDY, W.V., LANGLEY, F.M., MCCOWEN, K.D., ef al. Comparative evaluation of the thoracic impedance and isotope dilution methods for measuring cardiac output. Aerospace Med. 40: 532 (1969).

17. Naggar, C.Z. Dobnik, D.B., Flessas, A.P., et al. Accuracy of the stroke index as determined by the transthoracic electrical impedance method. Anesthesiology 42: 201 (1975).

18. Kubicek, W.B., Karnegis, J.N., Patterson, R.P., ef at. Development of evaluation of an impe- dance cardiac output system. Aerospace Med. 37 : 1208 (1966).

19. Hill, D.W. \& Merrifield, A.J. Left ventricular ejection and the Heather Index measured by noninvasive methods during postural changes in man. Acta Anaesth. Scand. 20:313 (1976).

20. Silgel, J.H., Fabian, M., Lankau, C., et al. Clinical and experimental use of thoracic impedance plethysmography in quantifying myocardial contractility. Surgery 67: 907 (1970).

21. Pomerantz, M., Baumgartner, R., Lauridson, J., et al. Transthoracic electrical impedance for the early detection of pulmonary edema. Surgery 66: 260 (1969)

22. Pomerantz, M., Delgado, F. \& Eiseman, B. Clinical evaluation of transthoracic electrical impedance as a guide to intrathoracic fluid volumes. Ann. Surg. 171: 686(1970).

23. LUEPKER, R. V., MiChaEL. J.R. \& WARBASSE, J.R. Transthoracic electrical impedance: quantitative evaluation of a non-invasive measure of thoracic fluid volume. Amer. Heart J. 85: 83 (1973).

24. Keller, G. \& BlumberG. A. Monitoring of pulmonary fluid volume and stroke volume by impedance cardiography in patients on hemodialysis. Chest 72: 56(1977).

25. Berman, I.R., Scheetz, W.L., Jenkins, E.B., $t$ al. Transthoracic electrical impedance as a guide to intravascular overload. Arch. Surg. 102:61 (1971).

RÉSUMÉ

La recherche de méthodes non-invasives pour la mesure du débit cardiaque, du travail myocarde, du contenu fluide du thorax et de l'état de la circulation périphérique, a gagné du terrain durant la dernière décennie. La cardiographie par impédance est un excmple des travaux qui ont porté fruit à ce sujet; découverte dès 1930, elle ne fut perfectionnée et utilisée à fond que trente ans plus tard, au cours des explorations lunaires Appolon. Il s'agit d'une méthode pléthysmographique électronique qui mesure l'impédance thoracique durant les phases du cycle cardiaque. Une formule dérivée par Kubicek et coll. permet le calcul du volume d'éjection, et donc du débit cardiaque, en fonction de changements d'impédance thoracique. La méthode permet aussi de mesurer le rapport des durées respectives de la contraction isovolémique ventriculaire et de la phase d'éjection (index Heather). Hill et coll. ont établi une formule par laquelle il est possible de mesurer la durée d'éjection ventriculaire gauche et Siegel et coll. pour leur part ont conçu une méthode de calcul de la contraction isométrique du myocarde en fonction de changements d'impédance thoracique.

Le cardiogramme par impédance s'obtient par l'encerclement de la base du cou et de la poitrine du malade par quatre rubans $(2.5 \mathrm{~cm}$ de large) en mylar aluminisé. Un courant électrique de 4 milliampères et de 100 kilohertz est introduit entre la seconde et la troisième électrode; son voltage amplifié permet d'obtenir la courbe des variations d'impédance thoracique par rapport au temps.

La pléthysmographie des membres s'obtient par le placement des électrodes autour de l'extrémité choisie dont elle mesure la circulation sanguine.

Plusieurs auteurs ont souligné le manque de précision de cette technique: on reconnait de façon générale, qu'elle surestime les valeurs mesurées. Cependant, la reproductibilité des résultats rend la technique utilisable pour mesurer des changements plutôt que des valeurs absolues.

Les erreurs au début sont attribuables au fait qu'on a assumé que le thorax était cylindrique et à contenu homogène; la morphologie individuelle des patients introduit des variations particulières qui se retrouvent dans la mesure de leur impédance thoracique.

La cardiographie par impédance possède deux avantages importants: la simplicité relative des appareils de mesure et leur prix économique.

De plus, elle peut s'employer durant l'anesthésie sans aucune crainte des complications qui accompagnent parfois l'emploi de méthodes invasives plus précises. La recherche du méthodes de mesures non-invasives demeure une priorité et nous croyons que la cardiographie par impédance représente une avance importante dans ce sens. 